\title{
THREE PERSPECTIVES ON SOCIAL PATHOLOGY
}

\author{
Václav Bělík
}

\begin{abstract}
The issue of social pathology is a multilayered topic which goes through a series of disciplines. It can be perceived mainly as a sociological topic. The paper presents the contexts of other disciplines which define the issue such as social deviations, respectively from the viewpoint of psychology and pedagogy as risk behaviour. The paper points to three possible views on social pathology. The first view is social pathology as a set of phenomena which are perceived as problematic by the society (deviating from the behaviour according to the norms of the society). The second view is social pathology as a field of study preparing graduates for the prophylaxis and treatment of pathologically social phenomena. The third view is social pathology as a study subject concerning not only the students of socially oriented fields but mainly the students who are to become teachers. They often tend to be important sources of social support and possible actors in the process of searching for and elimination of pathological phenomena in the period of childhood and adolescence.
\end{abstract}

\section{Keywords}

social pathology

The issue of social pathology forms the current discourse in social sciences not only in the Czech Republic, but also worldwide. The massive increase of phenomena that can be described as socially deviant is unusual for the society and we are looking for ways to describe socially unacceptable phenomena, explore them and find solutions and ways of preventing them. The subject matter of social pathology is the study of the issue of socially deviant behaviour.

Kraus (2014, p. 15) defines social deviation as "the violation of or substantial departure from some social standards of behaviour or from a group of standards as an expression of disregard for their requirements." Social deviation is not only the violation of standards sanctioned in legal, religious or moral terms but also the violation of any social standards, e.g. aesthetic. We distinguish between positive and negative deviations. Positive deviation then represent exaggeration and compliance with such standards in extreme ways, e.g. workaholism or abstinence. (Kraus et al., 2010). Kraus (2014, pp. 25-26) divides social deviance into three groups depending on its severity and social risk:

1. Undesirable social phenomena are such phenomena that occur in every society. These phenomena are becoming dangerous for society when their incidence exceeds a certain acceptable level. 
Unemployment, homelessness, homosexuality, divorce rate, injuries, illnesses and other may be listed as an example.

2. Asocial phenomena are more serious because they undermine the political, economic and moral foundations of society. Their common denominator is aggression. They include all violence, such as vandalism, domestic violence, bullying, spectator violence, extremism, but also cruelty towards animals.

3. We consider socially pathological phenomena as the most dangerous. These phenomena have the most negative consequences for the society. They include crime, addiction, prostitution or suicide.

Fischer and Škoda (2009) also define social pathological phenomena as unhealthy, abnormal and generally undesirable social phenomena. Social pathology denotes also the sociological discipline that focuses on patterns of such behaviour. It deals with the study and analysis of the causes and factors that led to the emergence of specific socially pathological phenomena. It also deals with the possibilities of prevention and therapy of these phenomena.

Social pathology can be seen as a particular problem area in the society which includes phenomena that we mark as socially pathological, or socially deviant in sociological terms. In school environment, these phenomena are defined by the National Strategy of Prevention of Risk Behaviour in Schooling Environments 2013-2018, which operates with the notion of risk behaviour, the busiest term denoting social pathologies in the educational reality to date.

The following phenomena are identified as risk behaviour (National Strategy, 2013):

- interpersonal aggression - aggression, bullying, cyberbullying, and other risk forms of, - communication through multimedia, violence, intolerance, anti-Semitism, extremism,

- racism and xenophobia, homophobia,

- delinquent behaviour in relation to material goods - vandalism, theft, graffiti and other,

- criminal offences and misdemeanours,

- truancy and non-fulfillment of school duties,

- addictive behaviour - the abuse of addictive substances, internet addiction, gambling,

- risks sports activities, injury prevention,

- risk behaviour in traffic, accident prevention,

- the spectrum of eating disorders,

- the negative influence of sects,

- hazardous sexual behaviour.

So how to define behaviour that we call as risk one?

The very concept comes from a psychological perspective on the problem and refers to behaviour through which an individual or a group endangers itself, but can also pose a threat to the society. Sobotková et al. (2014, p. 40) define the concept of risk behaviour thus: "we understand the concept of risk behaviour as superior to the concepts of problem, delinquent, antisocial and dissocial behaviour etc. These are often the subject of concepts and theories that try to explain their essence through either biological, psychological or social causes or their combinations." This term encompasses behaviour which results in a demonstrable increase in health, social, educational and other risks to individuals or to the society. It may endanger the health, life or social integrity of the individual. It is behaviour aimed against the interests of the society. (Kikalová and Kopecký, 2014) Risk is permanent and natural part of life and risk-taking is not an exceptional part of behaviour, it even 
has a relationship to personal or collective benefit and it develops from both emotional and rational components.

Skopalová (2010, p. 9) states that "its causes are considered to be those factors which influence its existence. These are phenomena or even entire processes that, to some extent, lead to and help committing unlawful activities. Risk behaviour is the result of mutually effective forces and factors. However, it cannot always be determined which to blame for the greatest share. Despite this, the first commonly mentioned factor is the family, followed by the influence of the peer group."

Most youth are successfully coping with radical changes in the body but in recent decades, increasing groups of the youth accept risky ways of life, often with negative consequences for their future lives. This is a worldwide trend. These facts are monitored and analyzed the most in the USA, especially since the late 1990's. In this context, we speak of "new morbidity of the youth". Research shows that these phenomena occur together, they often have the same causes and risk factors. Therefore, they actually constitute a syndrome. (Hamanová, 2000) In connection with risk behaviour, we speak of the so-called syndrome of adolescent risk behaviour. This denotes experimenting with various kinds of risky behaviour. It can be considered as part of the development of adolescents and in most cases it disappears during this period. This does not mean that an individual may be endangered by this behaviour later in life - meaning the risk behaviour associated with crossing the line of criminal activity.

According to the World Health Organization (WHO), adolescents are a separate risk group. Syndrome of adolescent risk behaviour is divided into three components:

- substance abuse (decreasing age of users, a growing share of the young female population),

- negative effects on psychosocial development (maladjustment, conduct disorders, aggression, delinquency, criminality, social phobia, self-mutilation, suicidal tendencies),

- risk behaviour in reproductive area (early sex, early parenthood, frequent change of partners, venereal diseases (Sobotková et al., 2014).

The media can also have a negative impact on the development of a young person. Especially TV shows where violence, inappropriate entertainment or aggression appear. This also applies to computer games which are popular today. The development of the child may be further influenced by family factors, e.g. unemployment of one or both parents. (Vašutová, Panáček, 2013)

A second perspective on social pathology can be social pathology as a field of study which belongs to the spectrum of helping professions (along with social education, social work, special education, addictology and other). This study programme called Social Pathology and Prevention can currently be studied at two university-type tertiary schools in the Czech Republic. It is the Department of Social Pathology and Sociology, Faculty of Education, University of Hradec Králové and Institute of Pedagogical and Psychological Sciences, Faculty of Public Policies, Silesian University in Opava.

Graduates of Social Pathology and Prevention are ready to perform the following professions:

- Worker in educational facilities for institutional and protective education (diagnostic institute, orphanage, orphanage with school, educational institution for the youth). In this context, they are close to the study and profiling of special pedagogy, which prepares specialists for educational work in ethopedic institutions (child behavioural specialists).

- Worker in educational institutions for the performance of preventive care (counselling centres). 
- Worker in non-profit organizations focusing on prevention and treatment of socially pathological phenomena, social counselling and social rehabilitation (senior homes, shelters, halfway houses, contact centres, drop-in centres, low-threshold facilities for children and the youth, after-care services, social services for families with children, citizens' advice bureaux). From the perspective of profiling, the graduates of this programme are close to social pedagogy or social work.

- Methodist of prevention in schools (students or graduates of teaching acting as prevention methodologists in schools choose the programme as an appropriate extension of their qualifications). In the Czech Republic, school prevention methodists and educational counsellors are trained using function education according to Act no. 563/2004 Coll. on Pedagogical Staff. In this context, it is akin to study programs of teaching and special pedagogy. The special pedagogy programme in its pedagogical form includes in the graduate's profile the focus on the work of a school methodist of prevention and educational counsellor.

- A worker of the Department of Social Affairs (social curator for adults, social curator for youth, Roma counsellor, consultant for national minorities, public guardian, a community planning worker, foster care worker, worker for domestic violence, maltreated and abused children). According to the amendment to Act no. 206/2009 Coll., new branch of social pathology is included among the branches of university studies which are a condition of professional competence of a social worker, which enables graduates to find wide application in the labour market.

- Worker of the Police of the Czech Republic within all police services (law enforcement, railway, traffic, immigration and border police), officer of the municipal police in the Czech Republic, police specialist - an expert in all police services.

- Worker in penitentiary and post-penitentiary care (prisons for custody enforcement, for service of incarceration sentences, and for security detention).

- Worker of the Probation and Mediation Service of the Czech Republic.

The graduates of Social Pathology and Prevention bear a number of skills acquired during their study through a system of pedagogical and other internships.

These competences include, in particular:

Informational Competence which is characterized by the fact that the graduates have gone through the entire spectrum of base pedagogical and psychological subjects, subjects oriented in the social fields (including medicine), as well as the legislation related to their future profession and practice. The study is also interwoven with other items that will help the graduates to have a range of knowledge not only in specially (narrowly) targeted fields, but especially in general purview (e.g. philosophy, sociology, anthropology, and other). They also have knowledge on the causes of deviant behaviour, including crime and are able to apply it, they have knowledge needed for the identification of effective strategies to protect public order and law enforcement, the necessary pedagogical and psychological knowledge to be involved in educating on prevention of socially pathological phenomena as well as issues of security and the law.

Altruistic Competence which bears the principles of working for others, not only to develop oneself, deep inner motivation for the development of individuals and groups. The graduates know the legal and ethical standards that form the framework of professional conduct in the field of security, prevention and the solution of all socially pathological phenomena; they can actively participate in or coordinate projects to support health (the healthy schools, the healthy city, the healthy social climate and the environment in workplaces). 
Egoistic competence egoistic which entails self-care, self-education, relaxation techniques preventing possible burnout syndrome.

Organizational and co-operational competence - the graduates know the procedures and methods of work with both the people who need help and protection, and those who act in a deviant way; they can organize social-pedagogical intervention with specific target groups in an interdisciplinary (inter-ministerial) manner and have the necessary knowledge to stimulate and coordinate programs of prevention of socially pathological phenomena.

Empathetic and communicative competence and problem-solving - the graduates master basic procedures in resolving conflicts between the individual and the society, and in life-crisis situations of clients, including techniques for coping with these difficult and critical life situations, they manage assertive behaviour and are equipped with creative skills.

The study programme Social Pathology and Prevention can be described as inter- and trans-disciplinary. From the above it is clear that it permeates numerous scientific and academic fields from which it chooses areas needed but also enters them retroactively, whether by description of the problems of social deviation, or by search for causes of these phenomena and design of procedures to prevent and ultimately eliminate these phenomena.

The third perspective on social pathology is the definition of social pathology as a study course occurring in the professional training of future teachers. It is therefore a course which in terms of undergraduate training at the University of Hradec Králové is included in the curricula of students of both socially oriented and instructionally oriented pedagogy. While it is compulsory and perceived as a profile course for the students of social pedagogy programmes, it is an elective course for students of the subject teaching programmes of pedagogy. Therefore, the course becomes marginal for these students in terms of their interest. It enters competition with courses whose demands are disproportionately lower. However, the usefulness of these courses for teachers is indisputable - especially to those full-time students who are just preparing for the career of a pedagogue and urgently need to be educated in this area which they are going to often encounter in practice. Hoferková (2013) points out that neither the prevention nor any possible intervention of risk behaviour in the population of university students have yet received sufficient attention. As Dulovics (2014) reports, sciences dealing with the field of assistance require people formed by very good undergraduate training who can be the bearers of a number of competences which include the competences relating to the issues of social pathology.

However, the reality is often different, as shown by the numbers of pedagogy students at the Faculty of Education, University of Hradec Králové, who do enter the course of social pathology (it should be noted that the total number of pedagogy students varies in thousands):

\begin{tabular}{|l|c|c|c|c|}
\hline Year & $\mathbf{2 0 1 2}$ & $\mathbf{2 0 1 3}$ & $\mathbf{2 0 1 4}$ & $\mathbf{2 0 1 5}$ \\
\hline Number of students & 11 & 7 & 12 & 15 \\
\hline
\end{tabular}

The challenge for undergraduate training remains in the effort to shift the Social Pathology course among the compulsory courses, which is not easy in the context of requirements for courses which should be contained in the common base of pedagogical studies. 
The instruction of the Social Pathology course focuses predominately on the following topics:

- Theories of social deviance. General characteristics of social deviations and their classification.

- The causes of social deviance in sociological, biological, psychological, and multi-factorial approach.

- Socially negative phenomena (unemployment, divorce, population imbalance, homelessness), their characteristics.

- Asocial phenomena and their characteristics (bullying, extremist movements, sects, behavioural disorders).

- Crime (the concept, development and current status in the Czech Republic, kinds, children's crime and juvenile delinquency).

- Prostitution (characteristics of the phenomenon, current situation, STDs).

- Suicide (characteristics of the problem, development and current status in he Czech Republic, forms of suicide of children and youth).

- Addition (general characteristics, stage of formation, typology).

- Alcoholism, nicotine addiction (characteristic of the problems, current state in the Czech Republic, the emergence and progress of these addictions).

- Non-alcoholic addiction (drugs, their classification, characteristics of physical and psychological additions).

- Other addictions and their characteristics (pathological gambling, workaholism).

- The issues of prevention and therapy of social deviance (types of prevention, forms and possibilities of prevention and therapy).

To illustrate the situation, it is interesting to point out and repeat the results of the surveys regarding these issues which have been carried out by the author of the present paper. The first is a content analysis of study programme curricula at teacher training faculties. This topic was mapped for 2006-2012 and the results of this investigation were described in detail in the author's monograph "Rizikové chování a jeho prevence v terciárním vzdělávání [Risk Behaviour and Its Prevention in Tertiary Education]" (Bělík, 2012). At this point, let us mention at least some of the results of this mapping.

The content analysis was performed for curricula of 29 faculties and institutions that provide undergraduate teacher training. The following table lists concrete outcomes for the area of primary and secondary courses. At this point, it should be noted that this is a list of courses that were current in 2007. Detailed results for individual faculties, including the five-year development until 2012 can be obtained from the author. It should be noted that the dynamics of these issues in undergraduate education is very small and the results are very similar. The economic aspect of universities has a great influence on this situation, as they are forced to economize and limit the amount of courses offered as compulsory elective and elective.

Results of content analysis:

\begin{tabular}{|l|c|c|c|}
\hline School X Course & $\begin{array}{c}\text { Number of Investigated } \\
\text { Faculties }\end{array}$ & $\begin{array}{c}\text { Primary } \\
\text { Courses }\end{array}$ & $\begin{array}{c}\text { Secondary } \\
\text { Courses }\end{array}$ \\
\hline Pedagogical Faculty & $10(9+1)$ & $39(27 \mathrm{E}, 12 \mathrm{CE})$ & 94 \\
\hline „Theological Faculties" & 5 & 0 & 15 \\
\hline Other & 13 & 0 & 11 \\
\hline
\end{tabular}

Note $: \mathrm{E}=$ elective course, $\mathrm{CE}=$ compulsory elective course 


\section{Conclusions on Research Findings - Content Analysis}

The results presented provide interesting information about undergraduate teacher training. We found that the preparation on faculties of education is incomparably superior in numbers of primary and secondary courses than at other faculties Based on the results, it can be generalized that courses we define as primary, do not occur more than secondary courses in any type of tertiary school. Based on the results from the table above, it is clear that theological faculties focus primarily on working with influencing valuesand standards. Science faculties and philosophical faculties devote very little curriculum to educational and psychological issues, while issues of social deviance are not studied at all.

The risk of these results lie in the possible contradiction between frequencies which we obtained by studying the courses syllabi and their actual content and quality of teaching which is difficult to detect. Another risk of these results is the possible conflict between materials that were provided to the research by the faculties and the actual number of students who take the courses.

\section{A Separate Investigation Focusing on Students' Knowledge}

In 2007, later in 2012, and newly also in 2015, the author implemented research to map the knowledge of students of teaching (teaching for $1^{\text {st }}$ and $2^{\text {nd }}$ stage primary and for secondary schools) and other educational staff, including students of socially oriented fields.

In terms of content, this was a didactic test which was thematically based on the currently valid document of the Ministry of Education, Youth and Sports "Strategy of the Prevention of Risk Behaviour" and was formally created on the basis of the so-called. Nimierko's taxonomy of creation and classification of didactic tests, which includes questions on knowledge, understanding of knowledge, standardized tasks and problem solving situations. Formal requirements of the test in 2007 and 2012, including the modified and upgraded version of 2015 are available from the author's work.

However, the interesting fact about the research is that according to the chosen classification, the results of students of teaching are completely opposed to the students of socially oriented disciplines. Results of student of teaching:

\begin{tabular}{|c|c|c|c|c|c|}
\hline $\begin{array}{c}\text { Classification } \\
\text { grade }\end{array}$ & Interval & $\begin{array}{c}\text { I. stage } \\
\text { primary school }\end{array}$ & $\begin{array}{c}\text { II. stage } \\
\text { primary school }\end{array}$ & $\begin{array}{c}\text { III. stage } \\
\text { secondary school }\end{array}$ & Total \\
\hline 1 & $19-21$ & 17 & 15 & 11 & 43 \\
\hline 2 & $17-18$ & 40 & 27 & 32 & 99 \\
\hline 3 & $15-16$ & 59 & 46 & 48 & 153 \\
\hline 4 & $13-14$ & 63 & 52 & 50 & 165 \\
\hline 5 & $0-12$ & 57 & 67 & 82 & 206 \\
\hline & Total & 236 & 207 & 223 & 666 \\
\hline
\end{tabular}


From the above table, it is clear that the vast majority of students of teaching who participated in the test would not be successful, or according to the chosen classification, their grade would be 3 and worse (equivalent to "C" and below).

Students of socio-educational fields had different results. This was done in both 2007 and 2012, and most recently in 2015 with a modified test, which takes into account other phenomena involving the topic of the risk behaviour syndrome:

\begin{tabular}{|c|c|c|c|}
\hline Grade & Number of Points & Frequency & \% \\
\hline 1 & $33-36$ & 2 & 2.15 \\
\hline 2 & $32-29$ & 44 & 47.32 \\
\hline 3 & $28-26$ & 30 & 32.25 \\
\hline 4 & $25-22$ & 14 & 15.05 \\
\hline 5 & $21-0$ & 3 & 3.23 \\
\hline
\end{tabular}

The results show that only two respondents (i.e. $2.15 \%$ ) would receive the test grade 1 ("A"), which corresponds to 33-36 points. The grade 2 ("B"), which corresponds to 32-29 points, would be given to 44 respondents (i.e. $47.32 \%$ ). 30 respondents (i.e. $32.25 \%$ ) would be classified by grades 3 ("C"), which corresponds to $28-26$ points. Grade 4 ("D") would be given to 14 respondents (i.e. $15.05 \%$ ), this result corresponds to $25-22$ points. Only 3 respondents (i.e. $3.23 \%$ ) gained less than 21 points, which corresponds to the classification grade 5 ("F").

\section{Conclusion}

This paper covers three perspectives on the issues of social pathology which the author encounters in the context of his professional activity at the Department of Social Pathology and Sociology of the Faculty of Education, University of Hradec Králové. It is social pathology as a problematic part of society, social pathology as a field of study and social pathology as a course which is important for pedagogues. The need for the discipline of social pathology is no longer in doubt today. This may be proven among other things by the significant amount of scientific literature that has been published (e.g. Fischer, Škoda - Social Pathology; Kraus, Hroncová - Social Pathology, and others), conferences on these issues that are held - for example Socialia 1997-2015 and other - research that is undertaken e.g. the research project carried out in the past in the workplace of the author entitled "Comprehensive Analysis of the Youth in the Eastern Bohemian Region" or "Analysis of Educational Reality of the Prevention of Social Deviance in Tertiary Education", and other. From the above it is clear that in practice, a number of problems occur which social pathology needs to be involved in, however, they need to be seen as invitations to improve the theory and practice in this field. 


\section{References}

Bělík, V. (2012). Rizikové chování a jeho prevence v terciárním vzdělávání pedagogů. [Risk Behaviour and Its Prevention in Tertiary Education of Pedagogues]. Hradec Králové: Gaudeamus.

Dulovics, M. (2014). Špecifiká pôsobenia sociálnych pedagógovv školskom prostredí. [Particularities of Social Influence of Social Pedagogues in School Environments]. Banská Bystrica: Belianum.

Fischer, S., \& Škoda, J. (2009). Sociální patologie: analýza př́čin a možnosti ovlivňování závažných sociálně patologických jevũ. [Social Pathology: An Analysis of the Causes and of the Possibilities of Influencing the Serious Socio-Pathological Phenomena]. Prague: Grada.

Hamanová, J., \& Kabíček, P. (2001). Syndrom rizikového chování v dospívání. [The Syndrome of Risk Behaviour in Adolescence]. Zdravotnické noviny, př́l. [Healthcare News, suppl]. Lékařské listy, [Medical Journal], L(4), p. 38-40.

Hoferková, S. (2013). Rizikové chování u studentů vysokých škol. [Risk Behaviour Among University Students]. In K. Večerka (Ed.), Prevence sociálních deviací - prání, naděje a realita: konference sekce sociální patologie MČSS. [Prevention of Social Deviance - Wishes, Hopes and Reality: A Conference Section on Social Pathology by Masaryk Czech Sociological Society]. Prague: Masaryk Czech Sociological Society.

Kikalová, K., \& Kopecký, M. (2014). Úvod do studia prevence závislostí dètí a dospívajících. [Introduction to the Study of Children's and Adolescent Addiction Prevention]. Olomouc: Palacký University in Olomouc.

Kraus, B. (2014). Základy sociální pedagogiky. [Basics of Social Pedagogy]. Prague: Portál.

Kraus, B. et al. (2004). Jak žije středoškolská mládež na počátku XXI. století: výzkum v Královéhradeckém kraji v letech 2000-2003. [How Do Secondary School Students Live at the Beginning of the XXI. Century: Research in Hradec Králové Region in 2000-2003]. Hradec Králové: Gaudeamus.

Kraus, B., \& Hroncová, J. (2010). Sociální patologie. [Social Pathology]. Hradec Králové: Gaudeamus.

Národní strategie primární prevence rizikového chování dètí a mládeže na období 2013-2018. [National Strategy for Primary Prevention of Risk Behaviour of Children and the Youth for the Period 2013-2018]. [online]. Accessed $1^{\text {st }}$ May 2015. http://www.kr-kralovehradecky.cz/cz/krajskyurad/skolstvi/prevence-soc-patologickych-jevu/narodni-strategie-primarni-prevence-rizikovehochovani-deti-a-mladeze-na-obdobi-2013---2018-62422/.

Skopalová, J. (2010).Záblesky bezpečí dítěte. [Flashes of Child Safety]. Olomouc: Palacký University in Olomouc.

Sobotková, V. et al. (2014). Rizikové a antisociální chování v adolescenci. [Risk and Antisocial Behaviour in Adolescence]. Prague: Grada.

The Education Act no. 561/2004 Coll. of the Czech Republic: The Pedagogical Staff Act no. 563/2004 Coll.; Implementing Decrees. 
Vašutová, M., \& Panáček, M. (2013). Mezi dětstvím a dospělostí: vybrané kapitoly z psychologie adolescence. [Between Childhood and Adulthood: Selected Chapters from Psychology of Adolescence]. Ostrava: Universitas Ostraviensis, Facultas Philosophica.

\section{Author}

PhDr. Václav Bělík, Ph.D.

Faculty of Education, University of Hradec Králové

Department of Social Pathology and Sociology

Rokitanského 62, 500 03, Hradec Králové, Czech Republic

vaclav.belik@uhk.cz 